\title{
Overview of Clinical Trials on Type 2 Diabetes Mellitus: A Comprehensive Analysis of the ClinicalTrials.gov Database
}

This article was published in the following Dove Press journal: Diabetes, Metabolic Syndrome and Obesity: Targets and Therapy

\author{
Jianyan Long ${ }^{1, *}$ \\ Ruiming Liang ${ }^{1}, *$ \\ Qiuyi Zheng ${ }^{1,2}$ \\ Gang Yuan ${ }^{3}$ \\ Ziyi $\mathrm{Xin}^{4}$ \\ Xinwen Chen ${ }^{2}$ \\ Fenghua Lai (D) ${ }^{2}$ \\ Yihao Liu (iD) ${ }^{1,2}$ \\ 'Clinical Trials Unit, The First Affiliated \\ Hospital of Sun Yat-Sen University, \\ Guangzhou 510080, People's Republic of \\ China; ' 2 Department of Endocrinology, \\ The First Affiliated Hospital of Sun Yat- \\ Sen University, Guangzhou 510080, \\ People's Republic of China; ${ }^{3}$ Phase \\ I Clinical Trial Center, The First Affiliated \\ Hospital of Sun Yat-Sen University, \\ Guangzhou 510080, People's Republic of \\ China; ${ }^{4}$ Department of Medical Records, \\ The First Affiliated Hospital of Sun Yat- \\ Sen University, Guangzhou 510080, \\ People's Republic of China \\ *These authors contributed equally to \\ this work
}

Correspondence: Yihao Liu Clinical Trials Unit, Department of Endocrinology, The First Affiliated Hospital of Sun Yat-Sen University, No. 58, ZhongShan Road 2, Guangzhou, Guangdong 510080, People's Republic of China

Tel +86-20-87755766

Email liuyih3@mail2.sysu.edu.cn

Fenghua Lai

Department of Endocrinology, The First Affiliated Hospital of Sun Yat-Sen

University, No. 58, ZhongShan Road 2,

Guangzhou, Guangdong 510080, People's

Republic of China

Tel +86-20-87332200

Email laifh@mail2.sysu.edu.cn
Purpose: A better understanding of the current features of type 2 diabetes mellitus (T2DM)related clinical trials is important for improving designs of clinical trials and identifying neglected areas of research. It was hypothesized that the trial registration policy promoted the designs of T2DM-related trials over the years. Therefore, this study aimed to present a comprehensive overview of T2DM-related clinical trials registered in the ClinicalTrials.gov database.

Methods: T2DM-related clinical trials registered in the ClinicalTrials.gov database were searched and assessed the characteristics of the relevant trials. We searched PubMed and Google Scholar for the publication statuses of the primary completed trials.

Results: Overall, 5117 T2DM-related trials were identified for analysis. Of the interventional trials, $71.5 \%$ had a primary treatment purpose while only $8.9 \%$ were prevention or health service. There were more interventional trials registered prior to patient recruitment between 2012 and 2019 than between 2004 and 2011 (44.6\% vs 19.9\%, P<0.001). The period between 2012 and 2019 also had more trials that enrolled $<100$ participants $(59.2 \%$ vs $50.9 \%)$, were single-center studies $(60.7 \%$ vs $50.6 \%)$, had non-randomized allocations $(11.3 \%$ vs $6.3 \%)$, were open-label $(49.2 \%$ vs $45.6 \%)$, and had smaller sample sizes than the period between 2004 and 2011 (all $P<0.001$ ). The five-year cumulative publication rates after primary completion of the trials were $<40 \%$.

Conclusion: Although the ClinicalTrials.gov database did not include all clinical trials, the trials registered in the ClinicalTrials.gov database still accounted for most of the clinical studies. Encouragingly, more interventional trials were registered prior to patient recruitment over the years. The majority of T2DM-related clinical trials focused on drug-related treatment, and trials regarding prevention in T2DM should be promoted. More attention should be paid to improve the publication and dissemination of clinical trials results.

Keywords: clinical trials, type 2 diabetes mellitus, ClinicalTrials.gov, publication status

\section{Introduction}

Diabetes is a chronic disease with an estimated global prevalence of 450 million. ${ }^{1}$ The public health toll of diabetes is on an upward trajectory, with its prevalence estimated to increase to 623 million by 2045 ; approximately $90 \%$ of these are type 2 diabetes mellitus (T2DM) patients. ${ }^{2}$ The health, social, and economic burdens caused by $\mathrm{T} 2 \mathrm{DM}$ and its complications present a major challenge to healthcare systems worldwide. ${ }^{3}$

T2DM is a complex endocrine and metabolic disorder. Genetic and environmental factors, including varying degrees of insulin resistance, dysfunction of 
pancreatic $\beta$ cells and $\alpha$ cells, and other endocrine disturbances, interact and cause organs damage..$^{4-7}$ Over the past two decades, many treatment options have been introduced, and the overall quality of life of T2DM patients has improved. However, due to the heterogeneity of the etiologies and complications of T2DM, glycemic control and complications prevention in T2DM are still challenging. ${ }^{8-10}$ A large number of clinical trials have been conducted worldwide to improve the management of T2DM.

Clinical trials, especially well-designed randomized clinical trials (RCTs), are the foundation of evidencebased medicine and the driving force behind the development of clinical medicine. In 2004, the International Committee of Medical Journal Editors (ICMJE) advocated that clinical trials should be registered in a public registry before participants were recruited to ensure transparency of the process. ${ }^{11,12}$ ClinicalTrials.gov, a web-based registry maintained by the National Library of Medicine (NLM) and National Institutes of Health (NIH), was created to provide the public and healthcare providers with easy access to information about clinical trials. Currently, the ClinicalTrials.gov database provides the most comprehensive information about ongoing and completed clinical studies worldwide. ${ }^{13}$ However, despite the availability of information regarding ongoing and completed clinical trials, a thorough evaluation of T2DM-related trials is yet to be conducted, and physicians still lack a comprehensive understanding of clinical trials on T2DM.

A better understanding of the current features of T2DM-related clinical trials is important for improving designs of clinical trials and identifying neglected areas of research, which will in turn improve the translatability of results into benefits for patients. Hence, we conducted this research to present a comprehensive overview of the features of T2DM-related clinical trials registered in the ClinicalTrials.gov database and to evaluate the publication statuses of these trials.

\section{Methods}

\section{Search and Selection of Relevant Registered Trials}

An established research protocol was developed in advance. On July 1, 2020, we searched the ClinicalTrials.gov database for relevant trials using the search term "type 2 diabetes mellitus" or "non-insulin dependent diabetes" or "T2DM". All available results were downloaded as XML files.
Subsequently, all the data were imported into an Excel form to facilitate further data selection, classification, and management. Two investigators (JL and RL) independently screened the "condition", "brief title", and "official title" of the trials. For each potentially eligible trial, the full document was retrieved and independently assessed for inclusion (JL and RL). Any discrepancies were resolved by consensus, and those unresolved through consensus were reviewed by a third investigator (FL). Trials started between 2004 and 2019 were included in our study. Trials with withdrawn, unknown, terminated, and expanded access statuses and trials included non-T2DM participants were excluded. Finally, all included clinical trials were classified manually in duplicate by two independent investigators (JL and RL). Inconsistencies were resolved by consensus, and those unresolved through consensus were classified by a third investigator (FL). This study was approved by the Research Ethics Committee of the First Affiliated Hospital of Sun Yat-sen University. Patient consent was not required in this study.

\section{Data Extraction}

A data extraction form was developed by a senior investigator (YL). Three investigators (JL, RL, and FL) were pre-trained in a pilot-testing phase to calibrate extraction criteria. The following variables were extracted by two investigators (JL and RL) independently using a standardized data extraction form: age of participants, sample size, study design, primary purpose of the trial, types of interventions, types of therapeutic drugs, region where the study was performed, centers, funding sources, start date, status of trial, duration of trial, and results of primary completed trials. Any disagreements were resolved by consensus, and those unresolved through consensus were reviewed by a third investigator (FL). If an industry was listed as the lead funder, the trial was classified as being funded by the industry. If the NIH was listed as the lead funder, the trial was considered NIH-funded. ${ }^{14}$ The time to primary completion was defined as the time from the start of the trial to the time the primary endpoint was reached. The duration of the trial was defined as the time from the start of the trial to the completion of the trial.

\section{Search for the Publication Statuses of Included Trials}

Two investigators (JL and RL) independently searched for peer-reviewed publications of trials in a stage of primary 
completion by using a standardized strategy. The "publications" field in the ClinicalTrials.gov database was identified and used to search for potentially matching publications. We then searched PubMed and Google Scholar by using brief titles and registration numbers in all the fields. The search for the publication statuses of the trials was updated and finalized by July 5, 2020. Publication was confirmed by matching the study characteristics outlined in the ClinicalTrials.gov database with the description in the published manuscript. The earliest article that reported primary outcome results was chosen if multiple publications were obtained from the same registered trial. Study protocols, commentaries, interim analyses, and other non-relevant publication types were excluded. A third investigator (FL) independently reconfirmed the selection and conducted a publication search for the studies that were found to be unpublished by the first two investigators. Differences were resolved by consensus.

\section{Statistical Analysis}

The year 2012, which was the mid timepoint of 2004-2019, was chosen as the cutoff to compare the characteristics of interventional trials. The number (percentage) of categorical variables and the median (interquartile range) of continuous variables were calculated. The $\chi^{2}$ test was used to compare categorical variables. Kaplan-Meier analysis was used to analyze the cumulative publication rates after primary completion of the trials. Trials that did have not a "completed" status were excluded from the analysis. All statistical tests were performed using SAS version 9.4 software (SAS, institute, Cary, NC), and a two-sided $P$ value $<0.05$ was considered statistically significant.

\section{Results}

\section{Distribution of T2DM-Related Clinical Trials}

A total of 7823 registered clinical trials were retrieved from the Clinicaltrials.gov database; 2706 of the clinical trials were started before 2004 and after 2019. Trials that had withdrawn $(n=120)$, unknown $(n=670)$, and terminated $(n=361)$ statuses and trials that included non-T2DM participants $(n=769)$ were excluded. A total of 5117 clinical trials were eligible for analysis, including 794 (15.5\%) observational trials and $4323(84.5 \%)$ interventional trials (Figure 1). Inter-rater agreement for selecting the trials for full-document review was excellent with a kappa of 0.92
(95\% CI $=0.91-0.94)$. The distribution of the eligible trials by year according to the time of registration was summarized in Figure 2. Overall, the number of registered T2DMrelated clinical trials has increased over the years. The number of trials registered between 2004 and 2009 increased rapidly but decreased slightly after 2009. Since 2012, the number of T2DM-related clinical trials registered each year has remained stable.

\section{Characteristics of the Interventional and Observational Trials}

Table 1 presents the characteristics of the interventional and observational trials. Fewer children were enrolled in the interventional trials than in the observational trials (3.3\% vs $22.2 \%)$. More interventional trials than observational trials were registered before patient recruitment (33.2\% vs $23.7 \%$ ), had fewer than 100 participants $(55.3 \%$ vs $27.9 \%)$, and were mainly focused on drugrelated therapy $(63.3 \%$ vs $52.6 \%$ ) (all $P<0.001$ ). Most T2DM-related clinical trials were conducted in the United States/Canada/Europe $(70.6 \%$ of the interventional trials and $63.8 \%$ of the observational trials). More interventional trials than observational trials were multiplecenter studies (33.9\% vs 20.8\%) and were funded by industries (54.5\% vs 46.2\%) (both $P<0.001$ ). Most of the included trials had a primary completed status $(83.3 \%$ of the interventional trials and $78.0 \%$ of the observational trials). After primary completion of the trials, interventional trials had more results available in the ClinicalTrials.gov database $(28.5 \%$ vs $8.3 \%)$ and more publications (31.8\% vs $19.5 \%)$ than observational trials (both $P<0.001$ ).

\section{Trend of Changes in the Characteristics of the Interventional Trials}

The characteristics of the T2DM-related interventional trials registered between 2004-2011 and 2012-2019 are listed in Table 2. More of the interventional trials registered between 2012 and 2019 were registered before patient recruitment than those registered between 2004 and 2011 (44.6\% vs 19.9\%); more of the trials registered between 2012 and 2019 also had fewer than 100 participants $(59.2 \%$ vs $50.9 \%)$, were single-center studies $(60.7 \%$ vs $50.6 \%)$, had non-randomized allocations $(11.3 \%$ vs $6.3 \%)$, and were open-label (49.2\% vs $45.6 \%$ ) (all $P<0.001)$. The proportion of intervention trials conducted in Asia increased from $17.7 \%$ to $26.1 \%$ during the two 


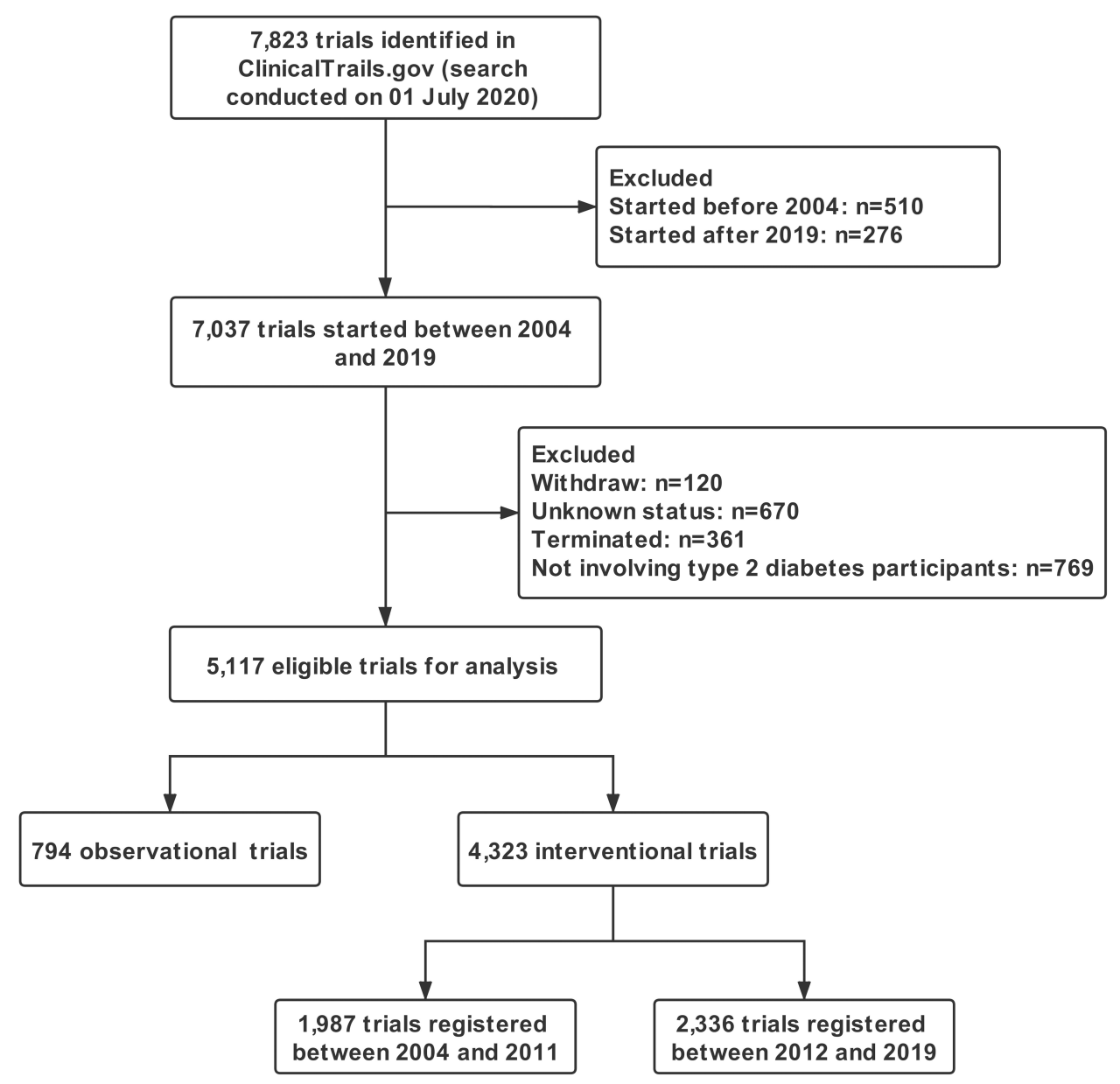

Figure I Flow chart of trial selection.

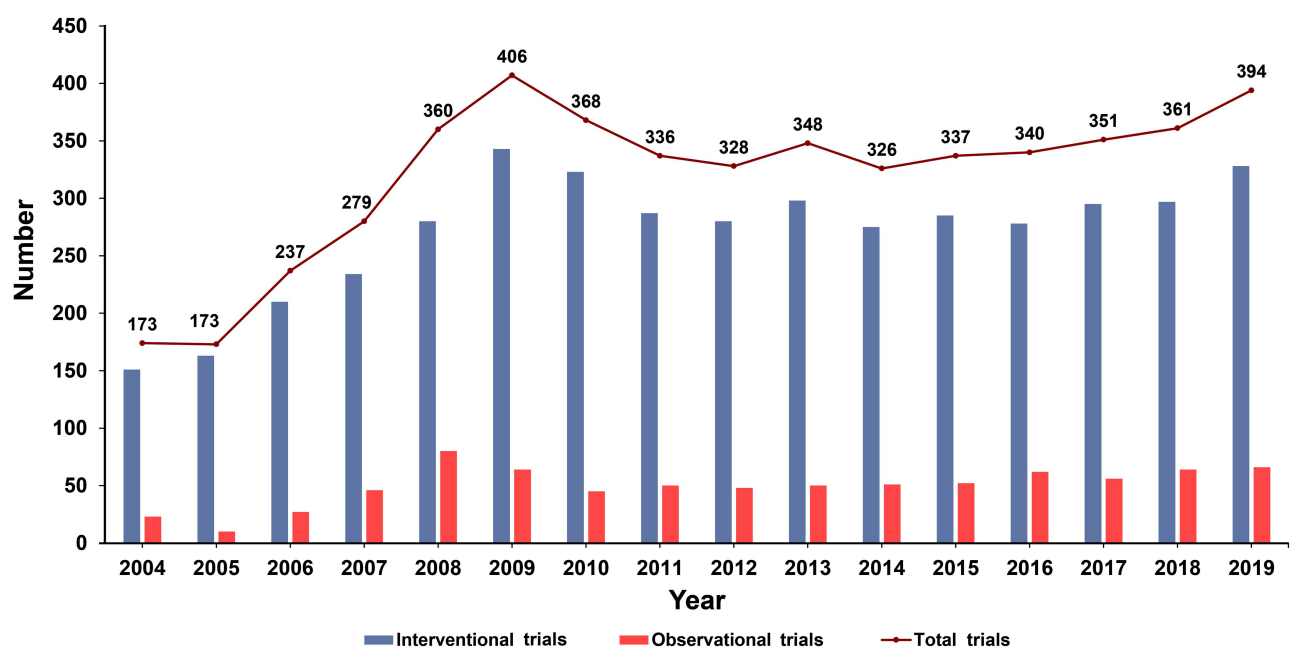

Figure 2 Distribution of the eligible clinical trials according to the registered year.

periods $(P<0.001)$. Of all the interventional trials, $71.5 \%$ had a primary treatment purpose while only $8.9 \%$ were prevention or health service. The proportion of intervention trials that focused on health services or preventive measures increased from $6.7 \%$ to $10.7 \%$ during the two periods $(P<0.001)$. 
Table I Characteristics of Interventional and Observational Trials

\begin{tabular}{|c|c|c|c|}
\hline Characteristics & $\begin{array}{l}\text { Interventional } \\
\text { Trials }(n=4323)\end{array}$ & $\begin{array}{l}\text { Observational } \\
\text { Trials }(n=794)\end{array}$ & $P$-value \\
\hline Participant & & & $<0.001$ \\
\hline $\begin{array}{l}\text { Adults and } \\
\text { children }^{\mathrm{a}} \\
\text { Only adults }\end{array}$ & $\begin{array}{l}144(3.3 \%) \\
4 \mid 79(96.7 \%)\end{array}$ & $\begin{array}{l}176(22.2 \%) \\
618(77.8 \%)\end{array}$ & \\
\hline Sample size & & & $<0.001$ \\
\hline $\begin{array}{l}\leq 50 \\
51-100 \\
101-200 \\
>200 \\
N A\end{array}$ & $\begin{array}{l}1584(36.6 \%) \\
808(18.7 \%) \\
639(14.8 \%) \\
1280(29.6 \%) \\
12(0.3 \%)\end{array}$ & $\begin{array}{l}138(17.4 \%) \\
83(10.5 \%) \\
83(10.5 \%) \\
489(61.6 \%) \\
1(0.1 \%)\end{array}$ & \\
\hline $\begin{array}{l}\text { Registered after } \\
\text { recruitment }\end{array}$ & & & $<0.001$ \\
\hline $\begin{array}{l}\text { No } \\
\text { Yes }\end{array}$ & $\begin{array}{l}1436(33.2 \%) \\
2887(66.8 \%)\end{array}$ & $\begin{array}{l}188(23.7 \%) \\
606(76.3 \%)\end{array}$ & \\
\hline $\begin{array}{l}\text { Intervention or } \\
\text { exposure }^{\mathrm{b}}\end{array}$ & & & $<0.001$ \\
\hline $\begin{array}{l}\text { Drugs } \\
\text { Surgery } \\
\text { Education or } \\
\text { lifestyle intervention } \\
\text { Dietary } \\
\text { Supplement } \\
\text { Device } \\
\text { Stem cell therapy } \\
\text { Others }\end{array}$ & $\begin{array}{l}2720(63.3 \%) \\
67(1.6 \%) \\
934(21.7 \%) \\
294(6.8 \%) \\
220(5.1 \%) \\
16(0.4 \%) \\
46(1.1 \%)\end{array}$ & $\begin{array}{l}289(52.6 \%) \\
28(5.1 \%) \\
83(15.1 \%) \\
9(1.6 \%) \\
47(8.6 \%) \\
1(0.2 \%) \\
92(16.8 \%)\end{array}$ & \\
\hline Region & & & $<0.001$ \\
\hline $\begin{array}{l}\text { US/Canada } \\
\text { Europe } \\
\text { Asia } \\
\text { Others }\end{array}$ & $\begin{array}{l}\text { I87| (43.3\%) } \\
\text { II80 (27.3\%) } \\
961(22.3 \%) \\
308(7.1 \%)\end{array}$ & $\begin{array}{l}190(23.9 \%) \\
317(39.9 \%) \\
230(29.0 \%) \\
57(7.2 \%)\end{array}$ & \\
\hline $\begin{array}{l}\text { Center } \\
\text { Single-center } \\
\text { Multi-center } \\
\text { NA }\end{array}$ & $\begin{array}{l}2425(56.1 \%) \\
1466(33.9 \%) \\
432(10.0 \%)\end{array}$ & $\begin{array}{l}526(66.2 \%) \\
165(20.8 \%) \\
103(13.0 \%)\end{array}$ & $<0.001$ \\
\hline Funder & & & $<0.001$ \\
\hline $\begin{array}{l}\text { Industry } \\
\mathrm{NIH} \\
\text { Others }\end{array}$ & $\begin{array}{l}2357(54.5 \%) \\
182(4.2 \%) \\
1784(41.3 \%)\end{array}$ & $\begin{array}{l}367(46.2 \%) \\
38(4.8 \%) \\
389(49.0 \%)\end{array}$ & \\
\hline $\begin{array}{l}\text { Primary completed } \\
\text { studies }\end{array}$ & & & $<0.001$ \\
\hline $\begin{array}{l}\text { No } \\
\text { Yes }\end{array}$ & $\begin{array}{l}421(9.7 \%) \\
3902(90.3 \%)\end{array}$ & $\begin{array}{l}118(14.9 \%) \\
676(85.1 \%)\end{array}$ & \\
\hline
\end{tabular}

(Continued)
Table I (Continued).

\begin{tabular}{|c|l|l|l|}
\hline Characteristics & $\begin{array}{c}\text { Interventional } \\
\text { Trials (n=4323) }\end{array}$ & $\begin{array}{l}\text { Observational } \\
\text { Trials (n=794) }\end{array}$ & P-value \\
\hline $\begin{array}{l}\text { Results of primary } \\
\text { completed studies }^{c}\end{array}$ & $2788(71.5 \%)$ & $620(91.7 \%)$ & $<0.001$ \\
\hline $\begin{array}{c}\text { No results } \\
\text { available } \\
\text { Results available }\end{array}$ & $1114(28.5 \%)$ & $56(8.3 \%)$ & $<0.001$ \\
\hline $\begin{array}{c}\text { Study completion } \\
\text { Completed } \\
\text { Ongoing }\end{array}$ & $\begin{array}{l}7600(83.3 \%) \\
\text { Publication }\end{array}$ & $\begin{array}{l}619(78.0 \%) \\
175(22.0 \%)\end{array}$ & \\
\hline $\begin{array}{c}\text { No publication } \\
\text { Published }\end{array}$ & $\begin{array}{l}2455(68.2 \%) \\
1145(31.8 \%)\end{array}$ & $\begin{array}{l}498(80.5 \%) \\
121(19.5 \%)\end{array}$ & $<0.001$ \\
\hline
\end{tabular}

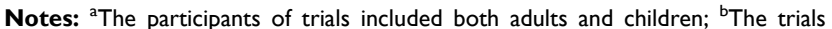
without available data were not included in the analysis; ${ }^{\mathrm{C}}$ The sum of number was the number of primary completed trials; ${ }^{\mathrm{d}}$ The sum of number was the number of completed trials.

Abbreviations: NA, not available; $\mathrm{NIH}$, National Institutes of Health.

\section{Distribution of Antidiabetic Drugs}

Figure 3 shows the summary of the common antidiabetic drugs studied in T2DM-related clinical trials and the trend of changes that occurred during the two periods between 2004-2011 and 2012-2019. Insulin, metformin, dipeptidyl peptidase-4 inhibitors, glucagon-like peptide-1 receptor agonists (GLP-1RAs), and sodium glucose cotransporter2 (SGLT-2) inhibitors were the antidiabetic drugs most commonly studied in the trials. The trials focused less on $\alpha$-glucosidase inhibitors and sulfonylureas. The proportion of trials that focused on GLP-1RAs and SGLT-2 inhibitors increased rapidly from 2012 to 2019 . The proportion of trials that focused on thiazolidinediones (TZDs) shrunk over time.

\section{Publication Status of Primary Completed Trials}

The one-year, three-year, and five-year cumulative publication rates since trial primary completion were $4.3 \%$, $26.0 \%$, and $33.1 \%$, respectively (Figure 4). Table 3 shows the detailed characteristics of the completed intervention trials according to publication status; $82.8 \%$ of the published trials reported positive outcomes. More published trials than unpublished trials enrolled more than 100 participants $(57.2 \%$ vs $38.3 \%)$, were multi-center 
Table 2 Trend of Changes in the Characteristics of Interventional Trials Registered Between Two Temporal Subsets

\begin{tabular}{|c|c|c|c|}
\hline Characteristics & $\begin{array}{l}\text { Registered } \\
\text { Between } \\
2004 \text { and } \\
2011 \\
(n=1987)\end{array}$ & $\begin{array}{l}\text { Registered } \\
\text { Between } \\
2012 \text { and } \\
2019 \\
(n=2336)\end{array}$ & $P$-value \\
\hline $\begin{array}{l}\text { Registered after } \\
\text { recruitment }\end{array}$ & & & $<0.001$ \\
\hline No & 395 (19.9\%) & $1041(44.6 \%)$ & \\
\hline Yes & 1592 (80.1\%) & 1295 (55.4\%) & \\
\hline Sample size & & & $<0.001$ \\
\hline $\begin{array}{l}\leq 50 \\
51-100 \\
101-200 \\
>200 \\
\text { NA }\end{array}$ & $\begin{array}{l}671(33.8 \%) \\
339(17.1 \%) \\
287(14.4 \%) \\
678(34.1 \%) \\
12(0.6 \%)\end{array}$ & $\begin{array}{l}913(39.1 \%) \\
469(20.1 \%) \\
352(15.1 \%) \\
602(25.8 \%) \\
0\end{array}$ & \\
\hline Purpose & & & $<0.001$ \\
\hline $\begin{array}{l}\text { Treatment } \\
\text { Diagnosis or } \\
\text { screening } \\
\text { Supportive care } \\
\text { Health service or } \\
\text { preventive } \\
\text { Basic science } \\
\text { NA }\end{array}$ & $\begin{array}{l}1539(77.5 \%) \\
25(1.3 \%) \\
53(2.7 \%) \\
133(6.7 \%) \\
120(6.0 \%) \\
117(5.9 \%)\end{array}$ & $\begin{array}{l}\text { I55I (66.4\%) } \\
54(2.3 \%) \\
|4|(6.0 \%) \\
25 \mid(10.7 \%) \\
208(8.9 \%) \\
|3|(5.6 \%)\end{array}$ & \\
\hline Phase $^{\mathrm{a}}$ & & & $<0.001$ \\
\hline $\begin{array}{l}\text { Phase I } \\
\text { Phase I/2 } \\
\text { Phase } 2 \\
\text { Phase 2/3 } \\
\text { Phase } 3 \\
\text { Phase } 4\end{array}$ & $\begin{array}{l}325(21.4 \%) \\
35(2.3 \%) \\
298(19.6 \%) \\
43(2.8 \%) \\
505(33.2 \%) \\
315(20.7 \%)\end{array}$ & $\begin{array}{l}27 \mid(21.1 \%) \\
24(1.9 \%) \\
208(16.2 \%) \\
27(2.1 \%) \\
359(27.9 \%) \\
398(30.9 \%)\end{array}$ & \\
\hline Allocation & & & $<0.001$ \\
\hline $\begin{array}{l}\text { Non-randomized } \\
\text { Randomized }\end{array}$ & $\begin{array}{l}125(6.3 \%) \\
1862(93.7 \%)\end{array}$ & $\begin{array}{l}263(11.3 \%) \\
2073(88.7 \%)\end{array}$ & \\
\hline Blinding $^{\mathrm{a}}$ & & & $<0.001$ \\
\hline $\begin{array}{l}\text { Blind } \\
\text { Open label }\end{array}$ & $\begin{array}{l}1073(54.4 \%) \\
898(45.6 \%)\end{array}$ & $\begin{array}{l}\text { I I } 86 \text { (50.8\%) } \\
\text { I I } 50 \text { (49.2\%) }\end{array}$ & \\
\hline Region & & & $<0.001$ \\
\hline $\begin{array}{l}\text { US/Canada } \\
\text { Europe } \\
\text { Asia } \\
\text { Others }\end{array}$ & $\begin{array}{l}962(48.4 \%) \\
546(27.5 \%) \\
352(17.7 \%) \\
127(6.4 \%)\end{array}$ & $\begin{array}{l}909(38.9 \%) \\
634(27.1 \%) \\
609(26.1 \%) \\
184(7.9 \%)\end{array}$ & \\
\hline
\end{tabular}

(Continued)
Table 2 (Continued).

\begin{tabular}{|c|l|l|l|}
\hline Characteristics & $\begin{array}{l}\text { Registered } \\
\text { Between } \\
2004 \text { and } \\
201 \text { I } \\
(\mathbf{n}=1987)\end{array}$ & $\begin{array}{l}\text { Registered } \\
\text { Between } \\
2012 \text { and } \\
2019 \\
(\mathbf{n}=2336)\end{array}$ & P-value \\
\hline Center & & & $<0.00 \mathrm{I}$ \\
\hline Single-center & $1006(50.6 \%)$ & $1419(60.7 \%)$ & \\
\hline $\begin{array}{l}\text { Multi-center } \\
\text { NA }\end{array}$ & $\begin{array}{l}768(38.7 \%) \\
213(10.7 \%)\end{array}$ & $\begin{array}{l}698(29.9 \%) \\
219(9.4 \%)\end{array}$ & \\
\hline Funder & $\begin{array}{l}1305(65.7 \%) \\
97(4.9 \%)\end{array}$ & $\begin{array}{l}1052(45.0 \%) \\
85(3.6 \%) \\
1199(51.3 \%)\end{array}$ & \\
\hline $\begin{array}{l}\text { Industry } \\
\text { NIH } \\
\text { Others }\end{array}$ & $585(29.4 \%)$ & $<0.00 \mathrm{I}$ \\
\hline
\end{tabular}

Note: ${ }^{a}$ The trials without available data were not included in the analysis. Abbreviations: NA, not available; NIH, National Institutes of Health.

studies (43.5\% vs 32.4\%), had randomized allocations (95.9\% vs $89.6 \%$ ), and used blinding methods $(57.2 \%$ vs $51.9 \%$ ) (all $P<0.001$ ). Published trials had more results available in the ClinicalTrials.gov database than unpublished trials ( $44.7 \%$ vs $24.4 \%, P<0.001)$.

\section{Discussion}

The aim of this study was to present a comprehensive overview of the T2DM-related clinical trials registered in the ClinicalTrials.gov database. To the best of our knowledge, this is the first comprehensive assessment of the characteristics of T2DM-related clinical trials. Our results showed that the T2DM-related clinical trials were mostly intervention trials. The interventional trials registered between 2012 and 2019 had smaller sample sizes, included more single-center studies, had more non-randomized allocations, and had more open-label studies than those registered between 2004 and 2011. The T2DM-related clinical trials mainly focused on drug-related therapy rather than preventive strategy. The proportion of trials that involved GLP-1RAs and SGLT-2 inhibitors increased rapidly over the years. The five-year cumulative publication rates after primary completion of the trials were lower than $40 \%$.

The results of the present study showed that more than $80 \%$ of T2DM-related clinical trials were interventional trials, a proportion that was similar to that of other chronic 

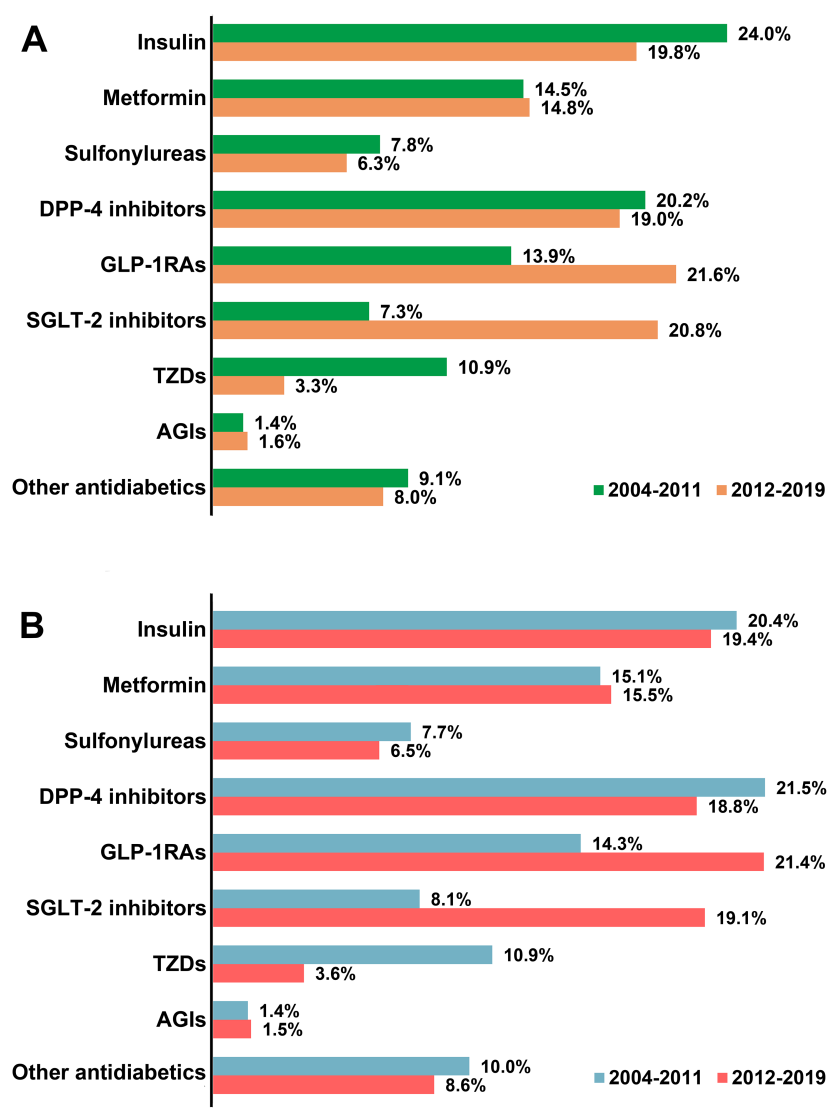

Figure 3 Distribution of the common antidiabetic drugs studied in all T2DMrelated clinical trials (A) and in T2DM-related intervention trials (B) between two temporal subsets (2004-20II and 2012-2019). The sum of the percentages may exceed $100 \%$ as categories were not mutually exclusive.

Abbreviations: DPP-4, dipeptidyl peptidase-4; GLP-IRAs, glucagon-like peptide-I receptor agonists; SGLT-2, sodium glucose cotransporter-2; TZDs, thiazolidinediones; AGls, $\alpha$-glucosidase inhibitors. disease trials. ${ }^{15,16}$ Registration of clinical trials has improved significantly since the ICMJE proposed the guideline that clinical trials should be registered in a public registry before participants are recruited. ${ }^{17,18}$ The results of the present study showed that there were more trials registered prior to patient recruitment between 2012 and 2019 than those registered between 2004 and 2011. However, the design of T2DM-related interventional clinical trials between 2012 and 2019 differed from those between 2004 and 2011. Firstly, the sample sizes of the intervention trials between 2012 and 2019 were generally small. This could probably be due to the rapid development and application of new antidiabetic drugs in the past decade $^{19}$ and the increased number of exploratory clinical trials that focused on the safety and efficacy of the new drugs. The new drugs were more expensive than the traditional antidiabetic drugs, and the financial burden on researchers or clinicians limited the recruitment of participants in trials. Another possible reason might be that the small-sample trials were less registered in the early years but forced to be registered in the later years due to the trial publication policy. Secondly, the proportion of multicenter trials was small. A potential reason for this may be that more trials were conducted in Asia between 2012 and 2019. There were huge differences in health policies and inequality in economic development across the Asian region, ${ }^{20,21}$ which may limit the cooperation of staff and administration in multiple centers. Finally, the proportion of clinical trials that involved blinding and randomized

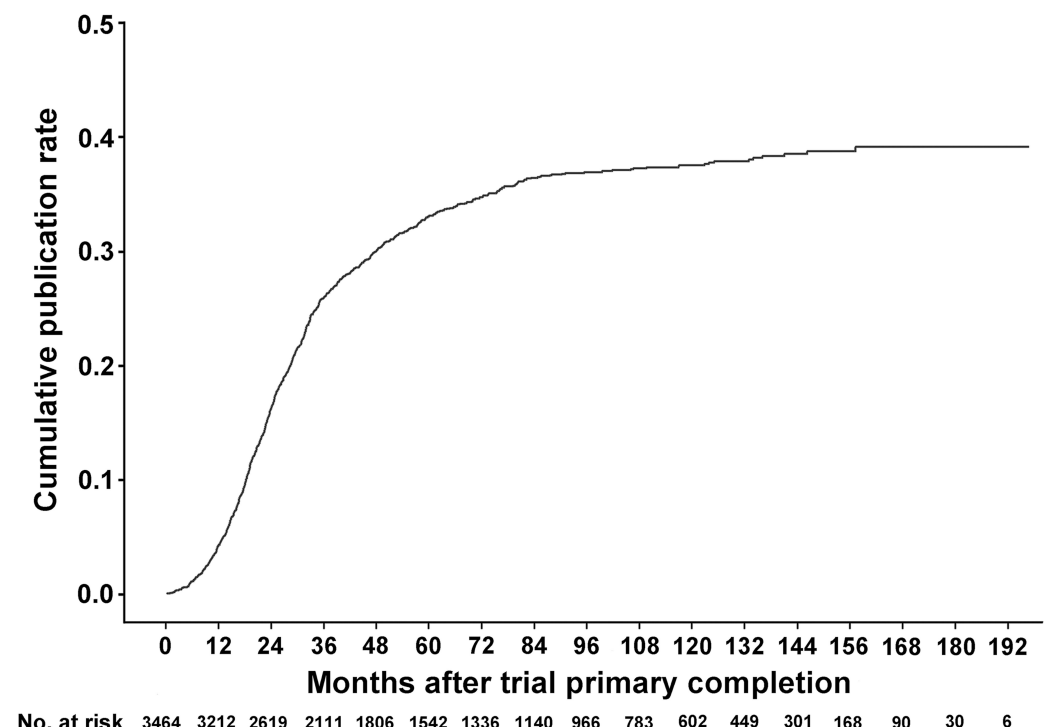

Figure 4 Cumulative publication rate curve since trial primary completion. Kaplan-Meier analysis was used. Trials with a "completed" status were included in the analysis. 
Table 3 Characteristics of Completed Interventional Trials According to the Publication Status ${ }^{\mathrm{a}}$

\begin{tabular}{|c|c|c|c|}
\hline Characteristics & $\begin{array}{l}\text { Unpublished } \\
(n=2455)\end{array}$ & $\begin{array}{l}\text { Published } \\
(n=|| 45)\end{array}$ & $P$-value \\
\hline Sample size & & & $<0.001$ \\
\hline$\leq 50$ & 1021 (4I.6\%) & $332(29.0 \%)$ & \\
\hline $51-100$ & $482(19.6 \%)$ & $158(13.8 \%)$ & \\
\hline $10 \mid-200$ & $370(15.1 \%)$ & $150(13.1 \%)$ & \\
\hline$>200$ & $570(23.2 \%)$ & $505(44.1 \%)$ & \\
\hline NA & $12(0.5 \%)$ & 0 & \\
\hline Phase $^{b}$ & & & $<0.001$ \\
\hline Phase I & $472(28.5 \%)$ & $80(9.6 \%)$ & \\
\hline Phase $1 / 2$ & 37 (2.2\%) & $13(1.6 \%)$ & \\
\hline Phase 2 & 321 (19.4\%) & $143(17.1 \%)$ & \\
\hline Phase $2 / 3$ & 35 (2.1\%) & $29(3.5 \%)$ & \\
\hline Phase 3 & $424(25.6 \%)$ & 355 (42.5\%) & \\
\hline Phase 4 & $368(22.2 \%)$ & $215(25.7 \%)$ & \\
\hline Allocation & & & $<0.001$ \\
\hline Non-randomized & $256(10.4 \%)$ & $47(4.1 \%)$ & \\
\hline Randomized & $2199(89.6 \%)$ & $\begin{array}{l}1098 \\
(95.9 \%)\end{array}$ & \\
\hline Blinding & & & 0.010 \\
\hline Blind & 1274 (5I.9\%) & $655(57.2 \%)$ & \\
\hline Open label & II 68 (47.6\%) & $486(42.4 \%)$ & \\
\hline NA & $13(0.5 \%)$ & $4(0.3 \%)$ & \\
\hline Purpose & & & 0.016 \\
\hline Treatment & | 752 (7|.4\%) & $880(76.9 \%)$ & \\
\hline $\begin{array}{l}\text { Diagnosis or } \\
\text { screening }\end{array}$ & 48 (1.9\%) & II (I.0\%) & \\
\hline Supportive care & $106(4.3 \%)$ & 39 (3.4\%) & \\
\hline $\begin{array}{l}\text { Health service or } \\
\text { preventive }\end{array}$ & 199 (8.1\%) & 87 (7.6\%) & \\
\hline Basic science & $202(8.2 \%)$ & $72(6.3 \%)$ & \\
\hline NA & I 48 (6.0\%) & $56(4.9 \%)$ & \\
\hline $\begin{array}{l}\text { Results of primary } \\
\text { completed studies }\end{array}$ & & & $<0.001$ \\
\hline No results available & 1856 (75.6\%) & $633(55.3 \%)$ & \\
\hline Results available & $599(24.4 \%)$ & $512(44.7 \%)$ & \\
\hline Outcome & & & \\
\hline Negative & - & 197 (17.2\%) & - \\
\hline Positive & - & $948(82.8 \%)$ & \\
\hline Region & & & $<0.001$ \\
\hline US/Canada & 1034 (42.2\%) & $54 \mathrm{I}(47.2 \%)$ & \\
\hline Europe & 671 (27.4\%) & $329(28.7 \%)$ & \\
\hline Asia & $578(23.6 \%)$ & $200(17.5 \%)$ & \\
\hline
\end{tabular}

(Continued)
Table 3 (Continued).

\begin{tabular}{|c|c|c|c|}
\hline Characteristics & $\begin{array}{l}\text { Unpublished } \\
(n=2455)\end{array}$ & $\begin{array}{l}\text { Published } \\
(n=|| 45)\end{array}$ & $P$-value \\
\hline Others & 170 (6.9\%) & $75(6.6 \%)$ & \\
\hline Center & & & $<0.001$ \\
\hline $\begin{array}{l}\text { Single-center } \\
\text { Multi-center } \\
\text { NA }\end{array}$ & $\begin{array}{l}1386(56.5 \%) \\
795(32.4 \%) \\
274(11.2 \%)\end{array}$ & $\begin{array}{l}534(46.6 \%) \\
498(43.5 \%) \\
113(9.9 \%)\end{array}$ & \\
\hline Funder & & & 0.071 \\
\hline $\begin{array}{l}\text { Industry } \\
\mathrm{NIH}\end{array}$ & $\begin{array}{l}1445(58.9 \%) \\
88(3.6 \%)\end{array}$ & $\begin{array}{l}703(61.4 \%) \\
52(4.5 \%)\end{array}$ & \\
\hline Others & $922(37.6 \%)$ & $390(34.1 \%)$ & \\
\hline $\begin{array}{l}\text { Registered after } \\
\text { recruitment }\end{array}$ & & & 0.011 \\
\hline $\begin{array}{l}\text { No } \\
\text { Yes }\end{array}$ & $\begin{array}{l}679(27.7 \%) \\
1776(72.3 \%)\end{array}$ & $\begin{array}{l}364(31.8 \%) \\
781(68.2 \%)\end{array}$ & \\
\hline Study duration (month) & $16.2(8.9,28.4)$ & $\begin{array}{l}20.3 \\
(13.2,32.5)\end{array}$ & $<0.001$ \\
\hline $\begin{array}{l}\text { Duration of primary } \\
\text { completion(month) }\end{array}$ & I5.2 (8.1,25.4) & $\begin{array}{l}18.3 \\
(12.2,28.9)\end{array}$ & $<0.001$ \\
\hline
\end{tabular}

Notes: ${ }^{2}$ Publication statuses of the trials were searched through PubMed and

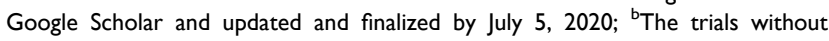
available data were not included in the analysis.

Abbreviations: NA, not available; NIH, National Institutes of Health.

designs shrunk. With the development of evidence-based medicine, well-designed RCTs play an important role in the establishment of health policies and in the decisionmaking of clinicians. A lack of randomization and blinding greatly increased the risk of bias in the results of trials. $^{22}$ Therefore, more attention should be paid to the design of T2DM-related clinical trials.

Drug-related therapy, especially antidiabetic drug therapy, has always been a hot topic in T2DM-related clinical trials. In the past 20 years, many antidiabetic drugs have been introduced, and this influenced the goal/objective of drug-related clinical trials. ${ }^{23}$ In the present study, the proportion of clinical trials on insulin and metformin was more than $40 \%$. The number of clinical trials on TZDs decreased significantly after 2012, whereas the number of clinical trials on GLP-1RAs and SGLT-2 inhibitors increased rapidly, a finding which was similar to the results of another study. ${ }^{24}$ TZDs were introduced in the late 1990s. Rosiglitazone was discontinued in Europe and 
its use was restricted in the USA in 2008 after reports of an association with cardiovascular risk. ${ }^{25}$ Pioglitazone was discontinued in 2011 in some European countries pending enquires into a possible risk of bladder cancer. $^{26}$ Therefore, clinical trials on TZDs decreased significantly between 2012 and 2019. GLP-1RAs were introduced in 2005, and the first SGLT-2 inhibitor, dapagliflozin, was approved in 2013 after the Food and Drug Administration issued its recommendation for the treatment of T2DM. Currently, clinical trials were conducted with special interest in their influence on the cardiovascular system and on nephropathy. ${ }^{27,28}$

The American Diabetes Association and the International Diabetes Federation emphasized that diabetes prevention should be the focus of future research. ${ }^{29,30}$ Previous studies demonstrated that lifestyle intervention and health education implementation may delay the onset of diabetes in high-risk persons. ${ }^{31-33}$ Therefore, additional research was needed to assess the effectiveness of prevention strategies in clinical practice and standardize their implementation. $^{34,35}$ We found that most T2DM clinical trials in the ClinicalTrials.gov database focused on drugrelated therapy, while only small percentages were primarily concerned with prevention, health services research, supportive care, diagnosis or screening. Although the ideal proportion of trials focused on prevention has not been established, the current T2DM-related clinical trials appeared to be inadequate for expanding and refining preventive strategies into the community setting.

The systematic reporting and publication of clinical research results provide a reliable basis for evidencebased medicine, facilitate the establishment of health policies, aids clinicians in decision-making, and promote the development of public health and clinical medicine. ${ }^{36}$ Following the announcement of the ICMJE trial registration policy in 2004, some organizations subsequently enacted laws and policies requiring the systematic reporting of aggregate results. In the USA, the Food and Drug Administration Amendments Act (FDAAA) of 2007 established a legal mandate requiring those responsible for initiating clinical trials to report summary results for certain trials. ${ }^{37}$ In 2016, the department of Health and Human Services promulgated regulations to implement, clarify, and expand legal requirements under FDAAA for trial results information submission. ${ }^{38}$ The Chinese Trial Registration and Publication Collaboration issued the second statement to implement the publication ethic of clinical trials in 2011. ${ }^{39}$ In June 2017, the ICMJE published a statement supporting data-sharing policy for clinical trials. ${ }^{40}$ However, in the present study, more than $70 \%$ of trials had no results available in the ClinicalTrials. gov database and the five-year cumulative publication rates of T2DM-related clinical trials after primary completion were lower than $40 \%$. Previous studies showed that publication rates among completed trials registered in ClinicalTrials.gov were less than $50 \%{ }^{41}$ Selective publication was an important factor that affects the publication of biomedical research. ${ }^{42}$ If trial results put either investigators/sponsors at financial risk or trial results contradicted investigators' beliefs, publications may be delayed or suppressed. $^{43}$ In addition, researchers, reviewers, and editors were generally more enthusiastic about positive or equivalence trials and less excited about negative trials. ${ }^{11}$ As $82.8 \%$ of the published trials in the present study reported positive results, our study results were in accordance with this opinion.

The limitations of our study should be addressed. Firstly, the ClinicalTrials.gov database does not include all clinical trials, and investigators may use other worldwide registries to fulfill the ICMJE-advocated mandatory registration guideline. However, the trials registered in the ClinicalTrials.gov database still account for most of the clinical studies in the World Health Organization International Clinical Trials Registry Platform. Secondly, the data for all clinical trials in the database were reported by researchers and the NLM cannot verify the validity of all trial information in the ClinicalTrials.gov database. Finally, the data of all trials in the ClinicalTrials.gov database were not always complete and up to date.

\section{Conclusion}

In summary, this study presented the first comprehensive overview of T2DM-related clinical trials registered in the ClinicalTrials.gov database. Our results indicated that there were more interventional trials registered prior to patient recruitment over the years. The majority of T2DMrelated clinical trials focused on drug-related treatment, and trials regarding prevention in T2DM should be promoted. More attention should be paid to improve the publication and dissemination of clinical trials results.

\section{Abbreviations}

FDAAA, Food and Drug Administration Amendments Act; GLP-1RAs, glucagon-like peptide-1 receptor agonists; ICMJE, International Committee of Medical Journal Editors; NIH, National Institutes of Health; 
NLM, National Library of Medicine; RCTs, randomized clinical trials; SGLT-2, sodium glucose cotransporter-2; TZDs, thiazolidinediones; T2DM, type 2 diabetes mellitus.

\section{Data-Sharing Statement}

The data will be made available at reasonable request from the corresponding author (YL).

\section{Author Contributions}

All authors made substantial contributions to conception and design, acquisition of data, or analysis and interpretation of data; took part in drafting the article or revising it critically for important intellectual content; agreed to submit to the current journal; gave final approval of the version to be published; and agree to be accountable for all aspects of the work.

\section{Funding}

This work was supported by the Research Fund of Medical Science and Technology of Guangdong Province (A2020132).

\section{Disclosure}

The authors report no conflicts of interest in this work.

\section{References}

1. Cho NH, Shaw JE, Karuranga S, et al. IDF diabetes atlas: global estimates of diabetes prevalence for 2017 and projections for 2045. Diabetes Res Clin Pract. 2018;138:271-281. doi:10.1016/j.diabres.2018.02.023

2. Holman N, Young B, Gadsby R. Current prevalence of type 1 and type 2 diabetes in adults and children in the UK. Diabet Med. 2015;32 (9):1119-1120. doi:10.1111/dme.12791

3. GBD DALYs, HALE Collaborators. Global, regional, and national disability-adjusted life-years (DALYs) for 315 diseases and injuries and healthy life expectancy (HALE), 1990-2015: a systematic analysis for the global burden of disease study 2015. Lancet. 2016;388 (10053):1603-1658. doi:10.1016/S0140-6736(16)31460-X.

4. Stumvoll M, Goldstein BJ, van Haeften TW. Type 2 diabetes: principles of pathogenesis and therapy. Lancet. 2005;365(9467):1333-1346. doi:10.1016/S0140-6736(05)61032-X

5. Yang Q, Graham TE, Mody N, et al. Serum retinol binding protein 4 contributes to insulin resistance in obesity and type 2 diabetes. Nature. 2005;436(7049):356-362. doi:10.1038/nature03711

6. Marcheva B, Ramsey KM, Buhr ED, et al. Disruption of the clock components CLOCK and BMAL1 leads to hypoinsulinaemia and diabetes. Nature. 2010;466(7306):627-631. doi:10.1038/nature09253

7. Samuel VT, Shulman GI. Mechanisms for insulin resistance: common threads and missing links. Cell. 2012;148(5):852-871. doi:10.1016/j. cell.2012.02.017

8. Mata-Cases M, Rodriguez-Sanchez B, Mauricio D, et al. The association between poor glycemic control and health care costs in people with diabetes: a population-based study. Diabetes Care. 2020;43 (4):751-758. doi:10.2337/dc19-0573

9. Satirapoj B, Pratipanawatr T, Ongphiphadhanakul B, Suwanwalaikorn S, Benjasuratwong Y, Nitiyanant W. Real-world evaluation of glycemic control and hypoglycemic events among type 2 diabetes mellitus study (REEDS): a multicentre, cross-sectional study in Thailand. BMJ Open. 2020;10(2):e031612. doi:10.1136/bmjopen-2019-031612
10. Stolar M. Glycemic control and complications in type 2 diabetes mellitus. Am J Med. 2010;123(Suppl 3):S3-S11. doi:10.1016/j. amjmed.2009.12.004

11. De Angelis C, Drazen JM, Frizelle FA, et al. Clinical trial registration: a statement from the international committee of medical journal editors. $N$ Engl J Med. 2004;351(12):1250-1251. doi:10.1056/ NEJMe048225

12. Hartung DM, Zarin DA, Guise JM, McDonagh M, Paynter R, Helfand M. Reporting discrepancies between the ClinicalTrials.gov results database and peer-reviewed publications. Ann Intern Med. 2014;160(7):477-483. doi:10.7326/M13-0480

13. Zwierzyna M, Davies M, Hingorani AD, Hunter J. Clinical trial design and dissemination: comprehensive analysis of clinicaltrials. gov and PubMed data since 2005. BMJ. 2018;361:k2130. doi:10.1136/bmj.k2130

14. Anderson ML, Chiswell K, Peterson ED, Tasneem A, Topping J, Califf RM. Compliance with results reporting at ClinicalTrials.gov. $N$ Engl J Med. 2015;372(11):1031-1039. doi:10.1056/NEJMsa 1409364

15. Califf RM, Zarin DA, Kramer JM, Sherman RE, Aberle LH, Tasneem A. Characteristics of clinical trials registered in ClinicalTrials.gov, 2007-2010. JAMA. 2012;307(17):1838-1847. doi:10.1001/jama.2012. 3424

16. Buffel DVC, Dechartres A, Battin C, Ravaud P, Boutron I. Exclusion of patients with concomitant chronic conditions in ongoing randomised controlled trials targeting 10 common chronic conditions and registered at ClinicalTrials.gov: a systematic review of registration details. BMJ Open. 2016;6(9):e012265. doi:10.1136/bmjopen-2016012265

17. De Angelis CD, Drazen JM, Frizelle FA, et al. Is this clinical trial fully registered? A statement from the international committee of medical journal editors. Ann Intern Med. 2005;143(2):146-148. doi:10.7326/0003-4819-143-2-200507190-00016

18. Zarin DA, Tse T, Williams RJ, Rajakannan T. Update on trial registration 11 years after the ICMJE policy was established. $N$ Engl J Med. 2017;376(4):383-391. doi:10.1056/NEJMsr1601330

19. Bull RI, Petersen SS, Juel J, Hansen MR, Andersen NH, Pareek M. Novel antidiabetic drugs and cardiovascular complications. Ugeskr Laeger. 2018;180(26).

20. Kumar P, Larrison C, Rodrigues SB, McKeithen T. Assessment of general practitioners' needs and barriers in primary health care delivery in Asia Pacific region. J Family Med Prim Care. 2019;8 (3):1106-1111. doi:10.4103/jfmpc.jfmpc_46_19

21. Tham TY, Tran TL, Prueksaritanond S, Isidro JS, Setia S, Welluppillai V. Integrated health care systems in Asia: an urgent necessity. Clin Interv Aging. 2018;13:2527-2538. doi:10.2147/CIA.S185048

22. Wood L, Egger M, Gluud LL, et al. Empirical evidence of bias in treatment effect estimates in controlled trials with different interventions and outcomes: meta-epidemiological study. BMJ. 2008;336 (7644):601-605. doi:10.1136/bmj.39465.451748

23. Tahrani AA, Bailey CJ, Del PS, Barnett AH. Management of type 2 diabetes: new and future developments in treatment. Lancet. 2011;378(9786):182-197. doi:10.1016/S0140-6736(11)60207-9

24. Rocha S, Ribeiro D, Fernandes E, Freitas MA. Systematic review on anti-diabetic properties of chalcones. Curr Med Chem. 2020;27 (14):2257-2321. doi:10.2174/0929867325666181001112226

25. Nissen SE, Wolski K. Effect of rosiglitazone on the risk of myocardial infarction and death from cardiovascular causes. $N$ Engl J Med. 2007;356(24):2457-2471. doi:10.1056/NEJMoa072761

26. Hillaire-Buys D, Faillie JL, Montastruc JL. Pioglitazone and bladder cancer. Lancet. 2011;378(9802):1543-1545. doi:10.1016/S01406736(11)61662-0

27. Deedwania P, Acharya T. Cardiovascular protection with anti-hyperglycemic agents. Am J Cardiovasc Drugs. 2019;19 (3):249-257. doi:10.1007/s40256-019-00325-9 
28. El MC, Riachy R, Khalil AB, Eid A, Azar S. SGLT2 inhibitors, GLP-1 agonists, and DPP-4 inhibitors in diabetes and microvascular complications: a review. Int J Endocrinol. 2020;2020:1762164. doi:10.1155/2020/1762164

29. Fonseca VA, Kirkman MS, Darsow T, Ratner RE. The American diabetes association diabetes research perspective. Diabetes Care. 2012;35(6):1380-1387. doi:10.2337/dc12-9001

30. Alberti KG, Zimmet P, Shaw J. International diabetes federation: a consensus on type 2 diabetes prevention. Diabet Med. 2007;24 (5):451-463. doi:10.1111/j.1464-5491.2007.02157.x

31. Gong Q, Zhang P, Wang J, et al. Morbidity and mortality after lifestyle intervention for people with impaired glucose tolerance: 30-year results of the Da Qing diabetes prevention outcome study. Lancet Diabetes Endocrinol. 2019;7(6):452-461. doi:10.1016/S22138587(19)30093-2

32. Jiang L, Johnson A, Pratte K, Beals J, Bullock A, Manson SM. Longterm outcomes of lifestyle intervention to prevent diabetes in American Indian and Alaska native communities: the special diabetes program for Indians diabetes prevention program. Diabetes Care. 2018;41(7):1462-1470. doi:10.2337/dc17-2685

33. Hill-Briggs F. 2018 Health care \& education presidential address: the American diabetes association in the era of health care transformation. Diabetes Care. 2019;42(3):352-358. doi:10.2337/dci18-0051

34. Dutton GR, Lewis CE. The look AHEAD trial: implications for lifestyle intervention in type 2 diabetes mellitus. Prog Cardiovasc Dis. 2015;58(1):69-75. doi:10.1016/j.pcad.2015.04.002

35. Lakey WC, Barnard K, Batch BC, Chiswell K, Tasneem A, Green JB. Are current clinical trials in diabetes addressing important issues in diabetes care? Diabetologia. 2013;56(6):1226-1235. doi:10.1007/s00125-013-2890-4

36. Ross JS, Tse T, Zarin DA, Xu H, Zhou L, Krumholz HM. Publication of NIH funded trials registered in ClinicalTrials.gov: cross sectional analysis. BMJ. 2012;344(jan03 1):d7292. doi:10.1136/bmj.d7292
37. Hirsch L. Trial registration and results disclosure: impact of US legislation on sponsors, investigators, and medical journal editors. Curr Med Res Opin. 2008;24(6):1683-1689. doi:10.1185/0300799 0802114849

38. Zarin DA, Tse T, Williams RJ, Carr S. Trial reporting in ClinicalTrials.gov - the final rule. $N$ Engl $J$ Med. 2016;375 (20):1998-2004. doi:10.1056/NEJMsr1611785

39. Liu X, Li Y, Jiang L, et al. To promote good research practice, good publication practice and good translation by implementing research ethic and publication ethic-the explanation document for the second statement of Chinese clinical trial registration and publication collaboration[Chinese]. Chin J Evid Based Med. 2011;11 (07):726-732.

40. Taichman DB, Sahni P, Pinborg A, et al. Data sharing statements for clinical trials - a requirement of the international committee of medical journal editors. $N$ Engl J Med. 2017;376(23):2277-2279. doi:10.1056/NEJMe1705439

41. Ross JS, Mulvey GK, Hines EM, Nissen SE, Krumholz HM. Trial publication after registration in ClinicalTrials.Gov: a cross-sectional analysis. PLoS Med. 2009;6(9):e1000144. doi:10.1371/journal. pmed.1000144

42. Decullier E, Lheritier V, Chapuis F. Fate of biomedical research protocols and publication bias in France: retrospective cohort study. BMJ. 2005;331(7507):19. doi:10.1136/bmj.38488.385995.8F

43. Blumenthal D, Campbell EG, Anderson MS, Causino N, Louis KS. Withholding research results in academic life science. Evidence from a national survey of faculty. JAMA. 1997;277(15):1224-1228. doi:10.1001/jama.277.15.1224

\section{Publish your work in this journal}

Diabetes, Metabolic Syndrome and Obesity: Targets and Therapy is an international, peer-reviewed open-access journal committed to the rapid publication of the latest laboratory and clinical findings in the fields of diabetes, metabolic syndrome and obesity research. Original research, review, case reports, hypothesis formation, expert opinion and commentaries are all considered for publication. The manuscript management system is completely online and includes a very quick and fair peer-review system, which is all easy to use. Visit http://www.dovepress.com/testimonials.php to read real quotes from published authors.

Submit your manuscript here: https://www.dovepress.com/diabetes-metabolic-syndrome-and-obesity-targets-and-therapy-journal 